moglobin does not affect the level of alkali-resistant haemoglobin. The poor reproducibility experienced by Beaven et al (1960) when using cyanmethaemoglobin has not been encountered.

\section{NORMAL VALUES}

Estimations of 75 normal non-pregnant females and 24 normal males between 18 and 45 years are shown in Figure 2. An upper limit of $0.9 \%$ has been taken as normal because the distribution becomes discontinuous above this level.

References

Beaven, G. H., Ellis, M. J., and White, J. C. (1960). Studies on human foetal haemoglobin. I. Detection and estimation. Brit. J. Haemat., 6, 1-22.

Betke, K., Marti, H. R., and Schlicht, I. (1959). Estimation of small percentages of foetal haemoglobin. Nature (Lond.), 184, 1877-1878.

Chernoff, A. (1953). Immunologic studies of hemoglobins. II. Quantitative precipitin test using anti fetal hemoglobin sera. Blood, $8,413-421$.

Christensen, J. (1968). Haemoglobin F: serological conditions and occurrence in normal adults and normal pregnant and postpartum women with particular reference to foeto-maternal haemorrhage. Dan. med. Bull., 15, 166-174.

Dacie, J. V., and Lewis, S. M. (1968). Practical Haematology, 4th ed. p. 37, Churchill, London.

Drabkin, D. L., and Austin, J. H. (1935). Spectrophotometric studies. II. Preparations from washed blood cells; nitric oxide hemoglobin, and sulf hemoglobin. J. biol. Chem., 112, 51-65.

Kristoffersen, K. (1961). An improved method for the estimation of small quantities of alkali-resistant hemoglobin in blood. Scand. J. clin. Lab. Invest., 13, 402-409.

Schroeder, W. A., Huisman, T. J. H., Shelton, J. R., and Wilson, J. B. (1970). An improved method for quantitative determination of human fetal hemoglobin. Analyt. Biochem., 35, $235-243$.

Singer, K., Chernoff, A. I., and Singer, L. (1951). Studies on abnormal hemoglobins. 1. Their demonstration in sickle cell anaemia and other hematologic disorders by means of alkali denaturation. Blood, 6, 413-428.

\section{A technique for demonstrating fibrinolysis by cutaneous bacteria}

DOROTHY A. SOMERVILLE From the Department $\mathbb{D}_{f}$ Bacteriology, St John's Hospital for Diseases of the Skin, London

Substances which convert plasminogen to plasmin ie, activators of plasminogen, derive from vario终 sources. They were first demonstrated in filtrat of haemolytic streptococci (Tillett and Garneis 1933) and since have been found in almost all fluids and organs of the body (Fearnley, 1965) and havis been demonstrated in culture filtrates of some straing of staphylococci (Elek, 1959). Substances collected from the skin surface have also been shown to have fibrinolytic activity (Dawber, Nishioka, and Ryap 1971) and it has been suggested that this activit together with the clot-promoting effect of surface lipids, is important in reconstituting the skin surfages following injury.

Dawber and his colleagues (1971) failed to find fibrinolytic activity among the bacteria of the normal flora of the skin. As some strains of Staphyle coccus aureus have long been known to produce staphylokinase (Elek, 1959) it was decided to stuce skin isolates of these organisms and the closefy linked groups, Staph. epidermidis and Micrococc species. The investigation was later extended include isolates of the cutaneous diphtheroids.

\section{Materials and Methods}

Fibrinolytic activity of bacteria has previously been demonstrated and measured using the fibrin plate technique (Astrup and Müllertz, 1952) in which 3 solution of fibrinogen is clotted with thrombin in 8 Petri dish and a small amount of the substance to be assayed placed on the fibrin so prepared. The plate is then incubated for a set period, usually about 20 hours, and lysis is shown as a clear zone which gives a measure of the fibrinolytic activity.

This technique is not ideal for testing larg numbers of strains of bacteria and it was thereforf modified and the tests performed in $50 \times 6 \mathrm{~mm}$ test tubes. In each sterile test tube were placed 0.5 i fibrinogen ( $1 \%$ in veronal buffer, $p \mathrm{H} 7.4), 0.02$. of $0.1 \mathrm{M}$ calcium chloride, and 1 drop of peptone water. All solutions were sterilized by filtratiogs before use. A large inoculum taken from an agat plate culture of the appropriate bacterial isolate

Received for publication 1 March 1972. 


\begin{tabular}{|c|c|c|c|c|c|c|c|}
\hline \multirow[t]{3}{*}{ Bacterium } & \multirow[t]{3}{*}{ No. of Strains } & \multicolumn{6}{|c|}{ Percentage Strains Lysing Fibrin Clots } \\
\hline & & \multicolumn{2}{|c|}{ Human Fibrinogen } & \multicolumn{2}{|c|}{ Bovine Fibrinogen } & \multicolumn{2}{|l|}{ Total } \\
\hline & & After $20 \mathrm{hr}$ & Total & After $20 \mathrm{hr}$ & Total & After $20 \mathrm{hr}$ & Total \\
\hline $\begin{array}{l}\text { Staph. aureus } \\
\text { Staph. epidermidis } \\
\text { Micrococcus species } \\
\text { Cutaneous diphtheroids }\end{array}$ & $\begin{array}{r}195 \\
80 \\
76 \\
110\end{array}$ & $\begin{array}{l}62 \\
42 \\
42 \\
33\end{array}$ & $\begin{array}{l}94 \\
65 \\
67 \\
81\end{array}$ & $\begin{array}{r}17 \\
6 \\
3 \\
-\end{array}$ & $\begin{array}{l}85 \\
29 \\
20 \\
17\end{array}$ & $\begin{array}{l}68 \\
44 \\
43 \\
33\end{array}$ & $\begin{array}{l}97 \\
68 \\
74 \\
83\end{array}$ \\
\hline
\end{tabular}

Table Fibrinolytic activity in cutaneous bacteria

be tested was added and finally $0.02 \mathrm{ml}$ sterile bovine thrombin $(0.5$ units). Thorough mixing was ensured using a vortex stirrer (Griffin) and the resulting fibrin clot in which the test strain was suspended was incubated at $37^{\circ} \mathrm{C}$ and examined after four and a half hours, 20 hours, and then daily until control tubes showed evidence of clot disintegration. Bovine and human fibrinogen (Sigma) were used and the control fibrin clots were stable for more than four days in the case of the bovine fibrinogen and over three days for the human fibrinogen. The addition of the small amount of peptone water did not affect the stability of the clot but minimal medium produced fibrinolysis within 20 hours.

In all, 195 strains of Staph. aureus, 156 strains of coagulase-negative staphylococci and micrococci, and 110 isolates of cutaneous diphtheroids were examined.

Culture filtrates of a limited number of the strains (12) were also tested, and the results obtained with these were similar to those obtained with the organisms themselves.

\section{Results}

Fibrinolytic activity amongst the isolates tested is shown in Table I. There was no evidence of activity after four-and-a-half hours either using the organisms themselves or the culture filtrates. The phage types of the Staph. aureus strains were known but the only significant difference between the various groups was the lower incidence of activity on bovine fibrinogen of the strains of phage group II $(38 \%$ as compared to $87 \%$ of the strains belonging to the other groups). There was no significant difference in incidence of activity amongst the Baird-Parker Staphylococcus and Micrococcus subgroups $\left(\chi^{2}=\right.$ 8.71 ; 7df) nor between the fluorescent and nonfluorescent diphtheroids tested $\left(\chi^{2}<0.01\right)$. Two isolates of Corynebacterium acnes were included but because of the difficulty of preserving a stable clot under anaerobic conditions, it was not possible to determine fibrinolytic activity.

\section{Comment}

Fibrinolytic activity is widespread amongst bacteria and can readily be demonstrated. The fibrin plate is a convenient method when only a few samples are being examined. However, there is a maximum of four or five specimens which can be assayed on one plate and even with this small number, difficulties arise when reading the results, for disintegration of the clot makes prolonged incubation impossible. Using test tubes, each strain may be separately tested for activity and the stability of the clot greatly improved; readings could easily be taken three to four days after inoculation. A quantitative assessment can be made by the time taken for lysis to appear.

\section{References}

Astrup, T., and Müllertz, S. (1952). The fibrin plate method for estimating fibrinolytic activity. Arch. Biochem., 40, 346-351.

Dawber, R. P. R., Nishioka, K., and Ryan, T. J. (1971). Fibrinolytic activity of skin surface lipids. Lancet, $1,193$.

Elek, S. D. (1959). Staphylococcus Pyogenes and its Relation to Disease. Livingstone, Edinburgh and London.

Fearnley, G. R. (1965). Fibrinolysis. Arnold, London.

Tillett, W. S., and Garner, R. L. (1933). The fibrinolytic activity of hemolytic streptococci. J. exp. Med., 58, 485-502. 